\title{
Effect of sirolimus on urinary bladder cancer T24 cell line Rosario Pinto-Leite ${ }^{1}$, Pedro Botelho1, Eufemia Ribeiro1, Paula A Oliveira*2 and Lucios Santos ${ }^{3,4}$
}

\author{
Address: ${ }^{1}$ Genetic Service, Cytogenetic laboratory, Hospital center of Trás-os-Montes and Alto Douro, 5000-508 Vila Real, Portugal, ${ }^{2}$ CECAV, \\ Department of Veterinary Sciences, CECAV, University of Trás-os-Montes and Alto Douro, 5001-911, Vila Real, Portugal, ${ }^{3}$ Department of Surgical \\ Oncology, Portuguese Institute of Oncology, Porto, Portugal and ${ }^{4}$ Health Faculty, Fernando Pessoa University, Porto, Portugal \\ Email: Rosario Pinto-Leite - mlleite@chtmad.min-saude.pt; Pedro Botelho - pedrobotelho15@gmail.com; \\ Eufemia Ribeiro - eufemiaribeiro@hospor.pt; Paula A Oliveira* - pamo@utad.pt; Lucios Santos - llarasantos@gmail.com \\ * Corresponding author
}

Published: 7 January 2009

Journal of Experimental \& Clinical Cancer Research 2009, 28:3 doi:10.1 186/I756-9966-28-3

This article is available from: $h t t p: / / w w w . j e c c r . c o m / c o n t e n t / 28 / I / 3$

(c) 2009 Pinto-Leite et al; licensee BioMed Central Ltd.

This is an Open Access article distributed under the terms of the Creative Commons Attribution License (http://creativecommons.org/licenses/by/2.0), which permits unrestricted use, distribution, and reproduction in any medium, provided the original work is properly cited.
Received: 4 November 2008

Accepted: 7 January 2009

\begin{abstract}
Background: Sirolimus is recently reported to have antitumour effects on a large variety of cancers. The present study was performed to investigate sirolimus's ability to inhibit growth in T24 bladder cancer cells.

Methods: T24 bladder cancer cells were treated with various concentrations of sirolimus. MTT assay was used to evaluate the proliferation inhibitory effect on T24 cell line. The viability of T24 cell line was determined by Trypan blue exclusion analysis.

Results: Sirolimus inhibits the growth of bladder carcinoma cells and decreases their viability. Significant correlations were found between cell proliferation and sirolimus concentration $(r=$ $0.830 ; p<0.01)$ as well as between cell viability and sirolimus concentration $(r=-0.896 ; p<0.01)$.

Conclusion: Sirolimus has an anti-proliferation effect on the T24 bladder carcinoma cell line. The information from our results is useful for a better understanding sirolimus's anti-proliferative activity in the T24 bladder cancer cell line.
\end{abstract}

\section{Background}

Bladder cancer is the second most common urologic malignancy and accounts for approximately $90 \%$ of cancers of the urinary tract. Is the fourth most incident cancer in male and ninth in females [1]. In industrialized countries, more than $90 \%$ of cases are originate in the urothelial epithelial cells (called urothelial cell carcinoma) [2]. At diagnosis, $75 \%$ are non-invasive bladder cancer. The invasive bladder cancers may spread outside the bladder and affect other organs. Bladder cancer's staging, treatment and prognosis depend on how deeply it has invaded urinary bladder [3].
Fortunately, about $80 \%$ of patients with non-muscle invasive disease can be successfully treated using the surgery. Historically, two-thirds of patients have tumour recurrence within 5 years. High-grade tumours have a significantly worse prognosis. Both high-grade $\mathrm{T} 1$ tumours and carcinoma in situ have the potential to progress and even metastasize [4]. Patients with invasive bladder cancer require a radical cystectomy. Controversy exists as to whether neoadjuvant or adjuvant chemotherapy improves survival in patients with invasive bladder cancer, despite a number of randomised controlled trials. So far there are no data to confirm what is the best combina- 
tion of treatments (neoadjuvant chemotherapy, adjuvant with or without radiotherapy) to treat invasive bladder cancer [5]. The modest results with currently drugs, suggest the urgent need to identify new agents [6]. Sirolimus is a macrocyclic lactone that was first discovered as a product of the soil bacteria Streptomyces hygroscopicus. It was originally used as an immunosuppressant drug to help prevent rejection in organ transplantation, particularly in kidney transplant operations, but the authors of a number of recent reports have indicated that it may have other potential biological effects as an anti-cancer medicine $[7,8]$. Both the immunosuppressive and anti-cancer properties of sirolimus are due to the inhibition of the mammalian target of the sirolimus (mTOR) signalling pathway, which controls mRNA translation and induces angiogenesis and cell proliferation. Angiogenesis and a high proliferative index correspond to a poor prognosis for urothelial bladder cancer patients $[9,10]$. Sirolimus forms a complex with the immunophilin prolyl isomerase FK binding protein complex (FKBP-12) that binds with high affinity to mTOR $[11,12]$. This interaction inhibits mTOR kinase activity and subsequently decreases the phosphorylation of $4 \mathrm{E}$ binding protein- 1 and the inhibition of the 40S ribosomal protein p70 S6 kinase [13-15]. Sirolimus's antineoplasic effects have been related to its capacity to inhibit the translation machinery involved in the regulation of G1- to S-phase transition in cell cycle $[16,17]$. Cell growth and proliferation in numerous cancer types are often regulated by the mammalian target of sirolimus (mTOR) pathway through p7056 kinase, ribosomal S6 protein, and eukaryotic initiation factor 4 E-binding protein 1 [18]. Recently there has been an enormous increase in our understanding of the molecular mechanisms underlying sirolimus's therapeutic anti-cancer properties. Alterations in the pathway regulating mTOR occur in many solid malignancies including bladder cancer. In vitro and in vivo models of bladder cancer have established the importance of the mTOR pathway in controlling cancer progression and metastasis [19]. The T24 cell line has been established from a highly malignant grade III human urinary bladder carcinoma [20]. This cell line can be easily grown in vitro and has been extensively used to evaluate the therapeutic effects of several anticancer drugs. Here, we describe the preliminary results of the study of the therapeutic effect of sirolimus against human T24 bladder cancer cell line in vitro using 3-(4,5-dimethylthiazol-2-yl)-2,5-diphenyltetrazolium bromide (MTT) assay for assessing cell proliferation and Trypan blue for assessing cell viability.

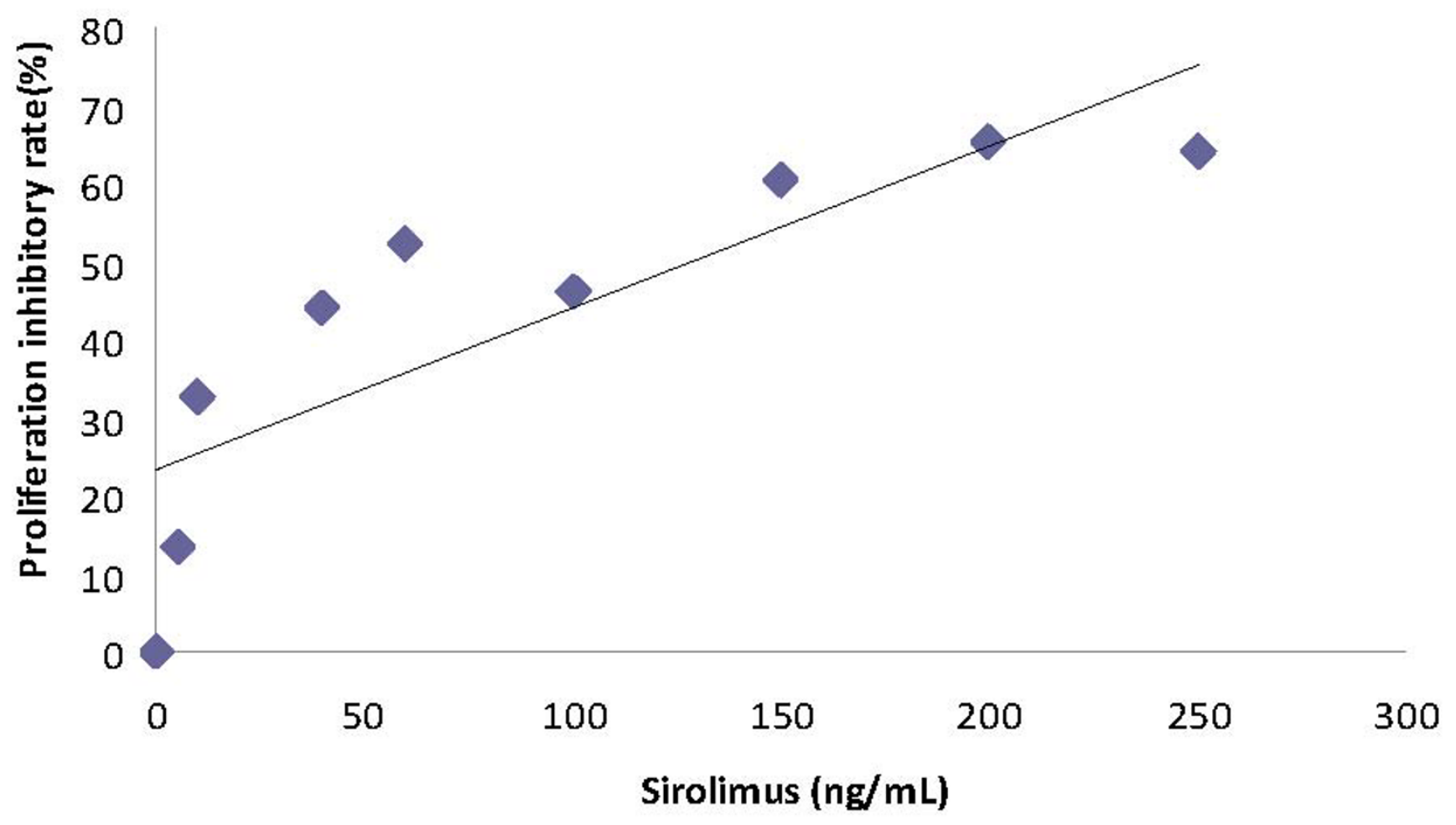

Figure I

Linear relationship between the proliferation inhibitory rate $(\%)$ and sirolimus concentration $(y=0.2074 x+$ 23.299; $\left.r^{2}=0.6882\right)$. 


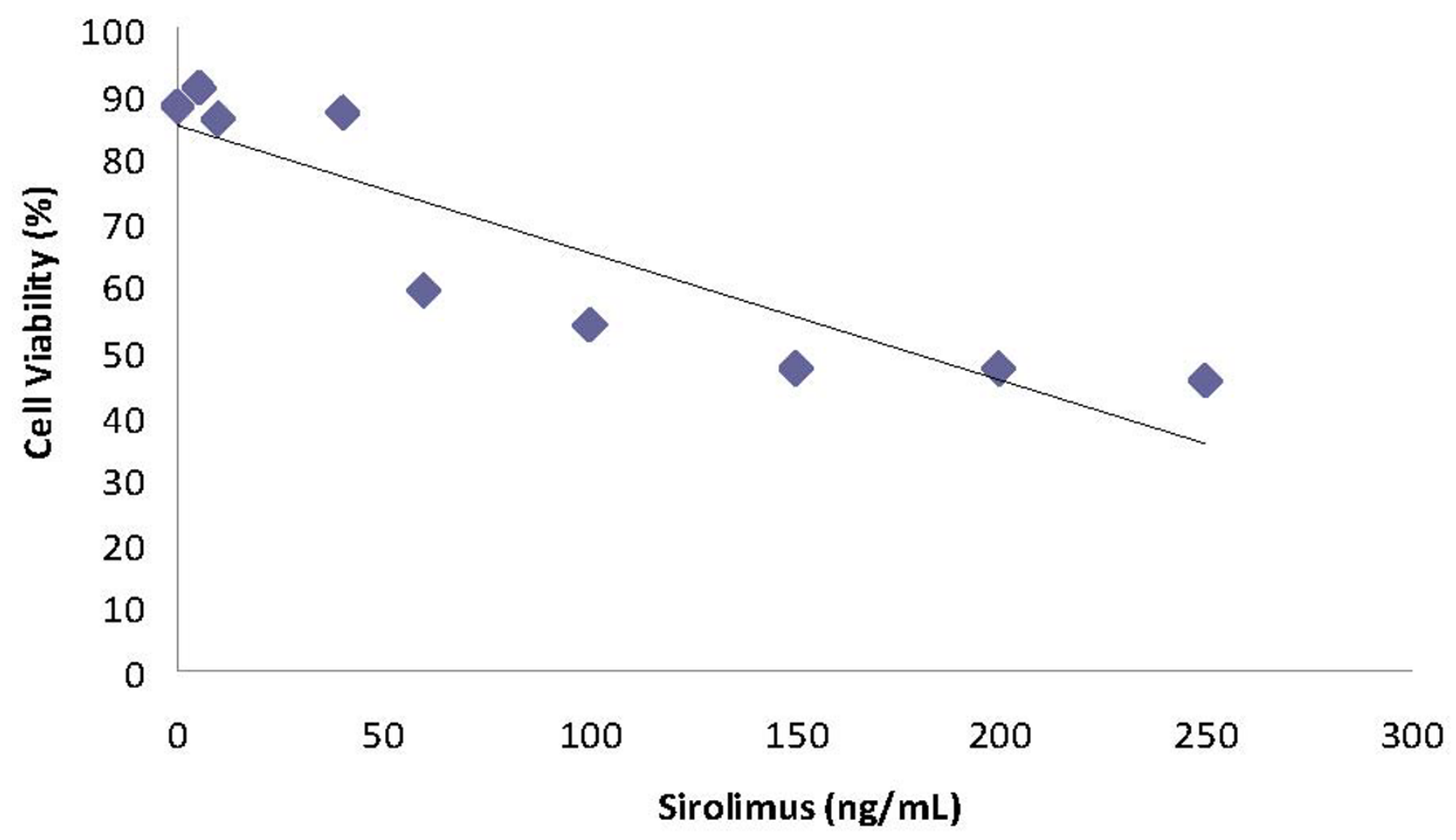

Figure 2

Linear relationship between the cell viability rate $(\%)$ and sirolimus concentration $\left(y=-0.1993 x+85.162 ; r^{2}=\right.$ 0.8023).

\section{Materials and methods Cell culture}

Cell line T24 was provided by a German collection of microorganisms and cell cultures (DSMZ, Düsseldorf, Germany). Cells were grown as a monolayer in complete RPMI (RPMI-1640 medium supplemented with 10\% fetal calf serum, $100 \mathrm{U} / \mathrm{mL}$ penicillin and $100 \mu \mathrm{g} / \mathrm{mL}$ streptomycin), in a humidified atmosphere with $7 \% \mathrm{CO}_{2}-93 \%$ air at $37^{\circ} \mathrm{C}$. Under these conditions, the plating efficiency was $70-90 \%$ and the doubling time was 9-10 h. Single cell suspensions were obtained by trypsinization of monolayer cultures.

\section{Drugs}

Sirolimus was purchased from Wyeth (Rapamune).

\section{Cell proliferation}

The anti-proliferative capacity of the treatments was assessed by the MTT [21]. This is based on the reduction of MTT by mitochondrial dehydrogenase of intact cells to a purple formazan product. Using a Neubauer counting chamber cells were counted and $2 \times 10^{4}$ cells were seeded in $1 \mathrm{ml}$ of medium in a 96-well culture plates and allowed to attach for 24 hours. Cells were treated with sirolimus (5 $\mathrm{ng} / \mathrm{mL}, 10 \mathrm{ng} / \mathrm{mL}, 40 \mathrm{ng} / \mathrm{mL}, 60 \mathrm{ng} / \mathrm{mL}, 100 \mathrm{ng} / \mathrm{mL}, 150$ $\mathrm{ng} / \mathrm{mL}, 200 \mathrm{ng} / \mathrm{mL}$, and $250 \mathrm{ng} / \mathrm{mL}$ ) for $72 \mathrm{~h}$, these doses were based on results published by other researchers $[22,23]$. Each of the concentrations above was regarded as one treated group while there was no sirolimus in the control group. After incubation, cell proliferation was evaluated by MTT assay according to the manufacturer's instructions. The MTT solution $(20 \mu \mathrm{L}, 5 \mathrm{mg} / \mathrm{ml})$ was added to each well $3 \mathrm{~h}$ prior to the end of the $72 \mathrm{~h}$ chemical treatment exposure period. The media were removed at the end of the $72 \mathrm{~h}$ exposure period. The insoluble purple formazan crystals were dissolved in $100 \mu \mathrm{L}$ DMSO/ well and the absorbance was detected at $570 \mathrm{~nm}$ and 690 nm using a spectrophotometer (U 2000, Hitachi). The proliferation inhibitory rate percentage was calculated as follows: proliferation inhibitory rate $(\%)=1-($ A570-A690) of experimental wells/(A570-A690) of control wellsX100. Assays were performed in triplicate.

\section{Assay of cell viability}

The viability of T24 cell line was determined by Trypan blue exclusion analysis. $0.2 \mathrm{ml}$ of the cells suspension treated with sirolimus at various concentrations were transferred to test tubes with $0.5 \mathrm{ml}$ of $0.4 \%$ Trypan blue 
Table I: Effect of sirolimus in T24 cancer cell line.

\begin{tabular}{|c|c|c|c|}
\hline Concentration & $\mathrm{A} 570 \mathrm{~nm}$ & $\mathrm{~A} 690 \mathrm{~nm}$ & Mean \pm SD \\
\hline & 0.525 & 0.201 & \\
\hline \multirow[t]{3}{*}{$0 \mathrm{ng} / \mathrm{mL}$} & 0.828 & 0.108 & $0.557 \pm 0.207$ \\
\hline & 0.828 & 0.201 & \\
\hline & 0.588 & 0.096 & \\
\hline \multirow{3}{*}{$5 \mathrm{ng} / \mathrm{mL}$} & 0.639 & 0.078 & $0.481 \pm 0.086$ \\
\hline & 0.72 & 0.33 & \\
\hline & 0.528 & 0.054 & \\
\hline \multirow{3}{*}{$10 \mathrm{ng} / \mathrm{mL}$} & 0.468 & 0.063 & $0.374 \pm 0.117$ \\
\hline & 0.47 & 0.225 & \\
\hline & 0.516 & 0.213 & \\
\hline \multirow[t]{3}{*}{$40 \mathrm{ng} / \mathrm{mL}$} & 0.489 & 0.087 & $0.310 \pm 0.087$ \\
\hline & 0.477 & 0.25 & \\
\hline & 0.78 & 0.489 & \\
\hline \multirow[t]{3}{*}{$60 \mathrm{ng} / \mathrm{mL}$} & 0.687 & 0.354 & $0.267 \pm 0.080$ \\
\hline & 0.339 & 0.162 & \\
\hline & 0.474 & 0.288 & \\
\hline \multirow{3}{*}{$100 \mathrm{ng} / \mathrm{mL}$} & 0.573 & 0.246 & $0.301 \pm 0.104$ \\
\hline & 0.657 & 0.267 & \\
\hline & 0.501 & 0.276 & \\
\hline \multirow[t]{3}{*}{$150 \mathrm{ng} / \mathrm{mL}$} & 0.42 & 0.318 & $0.22 \pm 0.115$ \\
\hline & 0.618 & 0.285 & \\
\hline & 0.504 & 0.417 & \\
\hline \multirow[t]{3}{*}{$200 \mathrm{ng} / \mathrm{mL}$} & 0.294 & 0.255 & $0.193 \pm 0.226$ \\
\hline & 0.576 & 0.123 & \\
\hline & 0.345 & 0.264 & \\
\hline \multirow[t]{2}{*}{$250 \mathrm{ng} / \mathrm{mL}$} & 0.3 & 0.27 & $0.199 \pm 0.249$ \\
\hline & 0.618 & 0.132 & \\
\hline
\end{tabular}

solution and $0.3 \mathrm{ml}$ of HBSS and mixed thoroughly. Allow to stand for 5 to 15 minutes. The percentage of viable cells was evaluated under the field microscope. Assays were performed in triplicate.

\section{Statistical analysis}

All experiments were performed in triplicate and data were expressed as mean values \pm SD. The Pearson productmoment correlation coefficient was used to evaluate the correlation (linear dependence) of cell proliferation, viability and sirolimus concentration. Data were analysed using SPSS 12 statistical software (SPSS Inc. USA) and statistical significance was set at $\mathrm{p}<0.05$.

\section{Results Cell proliferation}

The results of the MTT assay to detect sirolimus-induced anti-proliferative activity in T24 cell line are found in
Table 1. T24 cancer cells were treated with various concentrations of sirolimus. As shown in Figure 1, sirolimus had growth inhibition effects on T24 cancer cells in a dosedependent manner. Statistically, anti-proliferative activity was correlated with sirolimus concentration, the Pearson correlation of these two markers is $\mathrm{r}=0.830$ to $\mathrm{p}<0.01$.

\section{Cell viability}

The results of cell viability after the incubation of the T24 cell line with sirolimus at different concentrations are displayed in Figure 2. It can be seen from the figure that there was a concentration-dependent decrease in cell viability for all concentrations tested. A significant correlation was found between cell viability and sirolimus concentration $(\mathrm{r}=-0.896, \mathrm{p}<0.01)$.

\section{Discussion}

The findings of the present study revealed that sirolimus inhibits T24 bladder cancer cell proliferation and decrease the cell viability including in clinical dose of this mTOR inhibitor. These data may be relevant if we remember the action of the mTOR pathway. mTOR is a $290 \mathrm{kDa}$ serinethreonine kinase that regulates both cell growth and cell cycle progression through its ability to integrate signals from nutrient and growth factor stimuli [24]. Tumour angiogenesis may depend on mTOR signalling. Hypoxia induces production of vascular endothelial cell growth factor (VEGF) by tumour and stromal cells which may be partly controlled by mTOR signaling and through PI3KAkt-mTOR pathway [25]. Thus, the anti-tumour effects noted by inhibiting mTOR may be related to antiproliferative effects within tumour cells as well endothelial cells. Upstream effectors that signal through mTOR may up-regulate mTOR gene. Wu X et al (2004) showed that a specific inhibitor of PI3 kinase enzyme activity, Ly294002, potently suppressed the invasive properties of three highly invasive bladder tumour cell lines and 55\% of primary tumours from patients with bladder cancer had markedly high levels of phosphorylated Akt [26]. Thus, the inhibition of mTOR may inhibit abnormal cell proliferation, tumour angiogenesis, and abnormal cell metabolism and potentially enhance the efficacy of other cancer treatments. The biological mechanisms responsible for antiproliferative effect of sirolimus and the role of PI3K-AktmTOR pathway are under investigation [27]. Tanaka and Grossman (2003) demonstrate that PTEN can induce growth suppression and increase sensitivity to doxorubicin in bladder cancer cells and suggest that the PTEN gene and its pathways can be therapeutic targets for bladder cancer. To emphasize that, no results have been yet published on the activity of mTOR inhibitors against T24, or other, bladder cancer cell lines. Luan FL et al. (2002) showed that, sirolimus treatment alone, or with cyclosporine, prolonged the survival of mice inoculated with renal cancer cells or T24 human bladder cancer cells 
[28]. This is an indirect assumption of sirolimus effect against T24. The present study is the first address this issue. In the other hand, our team observed similar results, when we studied the effects of sirolimus in chemical induced urothelial cancers in ICR mice (data submitted). Sirolimus has been shown to inhibit the proliferation of various tumour cell lines including rhabdomyosarcoma, neuroblastoma, glioblastoma, small cell lung cancer, osteosarcoma, pancreatic cancer, breast cancer, prostate cancer, murine melanoma, leukaemia, and Bcell lymphoma [29-33].

Sirolimus enhances the anti-tumour effect of gemcitabine [34]. Now we intend to verify the efficacy of sirolimous mTOR inhibition, in other bladder cancer cell lines (5637, HT1376 and MC). Clinical results show that mTOR inhibitors are well tolerated and may induce prolonged stable disease and tumour regression in cancer patients [24]. Urgent research is needed to evaluate the real place of sirolimus or similar drugs in urothelial bladder cancer therapeutic.

\section{Conclusion}

Sirolimus inhibits T24 bladder cancer cell proliferation and decrease cell viability including in clinical dose, therefore should be considered to be a promising agents against bladder cancer. However, more positive data will be necessary.

\section{Competing interests}

The authors declare that they have no competing interests.

\section{Authors' contributions}

PLR and BP carried out cell cultures, performed the statistical analysis and drafted the manuscript, RE participated in its design, OPA helped to draft the manuscript and revised the manuscript, SL supervised experimental work and revised the manuscript. All authors read and approved the final manuscript.

\section{References}

I. Jemal A, Siegel R, Ward E, Murray T, Xu J, Thun MJ: Cancer statistics 2007. CA Cancer J Clin 2007, 57:43-66.

2. Parkin DM, Bray F, Ferlay J, Pisani P: Global Cancer Statistics, 2002. CA Cancer J Clin 2005, 55:74-108.

3. Crawford J: The origins of bladder cancer. Lab Invest 2008, 88:686-693.

4. Dalbagni G: The Management of Superficial Bladder Cancer. Nat Clin Pract Urol 2007, 4:254-260.

5. Choueiri T, Raghavan D: Chemotherapy for muscle-invasive bladder cancer treated with definitive radiotherapy persisting uncertainties. Nat Clin Pract Oncol 2008, 5:444-454.

6. Sternberg CN, Donat SM, Bellmunt J, Millikan RE, Stadler W, De Mulder P, Sherif A, Maase H von der, Tsukamoto T, Soloway MS: Chemotherapy for bladder cancer: treatment guidelines for neoadjuvant chemotherapy, bladder preservation, adjuvant chemotherapy, and metastatic cancer. Urology 2007, 69:62-79.

7. Wan X, Helman L]: The biology behind $\mathbf{m T O R}$ inhibition in sarcoma. Oncologist 2007, 12:1007-1018.

8. Cloughesy TF, Yoshimoto K, Nghiemphu P, Brown K, Dang J, Zhu S, Hsueh T, Chen Y, Wang W, Youngkin D, Liau L, Martin N, Becker D,
Bergsneider M, Lai A, Green R, Oglesby T, Koleto M, Trent J, Horvath S, Mischel PS, Mellinghoff IK, Sawyers CL: Antitumor Activity of Rapamycin in a Phase I Trial for Patients with Recurrent PTEN-Deficient Glioblastoma. PLoS Med 2008, 5:e2I.

9. Santos L, Amaro T, Costa C, Pereira S, Bento MJ, Lopes P, Oliveira J, Criado B, Lopes C: Ki-67 index enhances the prognostic accuracy of the urothelial superficial bladder carcinoma risk group classification. Int J Cancer 2003, 105:267-272.

10. Pignot G, Bieche I, Vacher S, Güet C, Vieillefond A, Debré B, Lidereau R, Amsellem-Ouazana D: Large-scale Real-time Reverse Transcription-PCR Approach of Angiogenic Pathways in Human Transitional Cell Carcinoma of the Bladder: Identification of VEGFA as a Major Independent Prognostic Marker. Eur Urol 2008 in press. doi:10.1016/j.eururo.2008.05.027

II. Huang S, Houghtoun PJ: Inhibitors of mammalian target of rapamycin as a novel agents: from bench to clinic. Curr Opinion Invest Drugs 2002, 3:295-304.

12. Dutcher JP: Mammalian target of rapamycin inhibition. Clin Cancer Res 2004, 10:6382-6387.

13. Hidalgo M, Rowinsky EK: The rapamycin-sensitive signal transduction pathway as a target for cancer therapy. Oncogene 2000, 27:6680-6686.

14. Dudkin L, Dilling MB, Cheshire PJ, Harwood FC, Hollingshead M, Arbuck SG, Travis R, Sausville EA, Houghton PJ: Biochemical correlates of $m$ TOR inhibition by the rapamycin ester $\mathrm{CCl}-779$ and tumor growth inhibition. Clin Cancer Res 200I, 7: I758-I 764.

15. Yu K, Toral-Barza L, Discafani C, Zhang WG, Skotnicki J, Frost P, Gibbons J]: $m T O R$, a novel target in breast cancer: the effect of CCI-779, an mTOR inhibitor, in preclinical models of breast cancer. Endocr Relat Cancer 200I, 8:249-258.

16. Fingar DC, Richardson CJ, Tee AR, Cheatham L, Tsou C, Blenis J: mTOR controls cell cycle progression through its cell growth effectors S6KI and 4E-BPI/eukaryotic translation initiation factor 4E. Mol Cell Biol 2004, 24:200-216.

17. Gingras $A C$, Raught $B$, Sonenberg N: mTOR signaling to translation. Curr Top Microbiol Immunol 2004, 279: I69-197.

18. Sabatini DM: $\mathbf{m T O R}$ and cancer: insights into a complex relationship. Nat Rev Cancer 2006, 6:729-734.

19. Garcia JA, Danielpour D: Mammalian target of rapamycin inhibition as a therapeutic strategy in the management of urologic malignancies. Mol Cancer Ther 2008, 7: I 347-I354.

20. Bubeník J, Baresová M, Viklický V, Jakoubková J, Sainerová H, Donner $\mathrm{J}$ : Established cell line of urinary bladder carcinoma (T24) containing tumour-specific antigen. Int J Cancer 1973, II:765-773.

2I. Zhang JF, Liu JJ, Lu MQ, Cai CJ, Yang Y, Li H, Xu C, Chen GH: Rapamycin inhibits cell growth by induction of apoptosis on hepatocellular carcinoma cells in vitro. Transpl Immunol 2007, 17:162-168.

22. Lang SA, Gaumann A, Koehl GE, Seidel U, Bataille F, Klein D, Ellis LM, Bolder U, Hofstaedter F, Schlitt HJ, Geissler EK, Stoeltzing O: Mammalian target of rapamycin is activated in human gastric cancer and serves as a target for therapy in an experimental model. Int J Cancer 2007, 120:1803-1810.

23. Weppler SA, Krause M, Zyromska A, Lambin P, Baumann M, Wounters BG: Response of U87 glioma xenografts treated with concurrent rapamycin and fractionated radiotherapy: possible role for thrombosis. Radiother Oncol 2007, 82:96-104.

24. Dancey JE: Therapeutic targets: MTOR and related pathways. Cancer Biol Ther 2006, 5:1065-1073.

25. Gao N, Zhang Z, Jiang BH, Shi X: Role of PI3K/AKT/mTOR signaling in the cell cycle progression of human prostate cancer. Biochem Biophys Res Commun 2003, 3 I 0: I I 24-32.

26. Wu X, Obata T, Khan Q, Highshaw RA, De Vere White R, Sweeney $C:$ The phosphatidylinositol-3 kinase pathway regulates bladder cancer cell invasion. BJU Int 2004, 93:143-I50.

27. Tanaka M, Grossman HB: In vivo gene therapy of human bladder cancer with PTEN suppress tumor growth, downregulates phosphorylated Akt, and increases sensitivity to doxorubicin. Gene Ther 2003, 10:1636-1642.

28. Luan FL, Hojo M, Maluccio M, Yamaji K, Suthanthiran M: Rapamycin blocks tumor progression: unlinking immunosuppression from antitumor efficacy. Transplantation 2002, 73:I565-1572.

29. Kasukabe T, Okabe-Kado J, Kato N, Sassa T, Honma Y: Effects of combined treatment with rapamycin and cotylenin $A$, a novel differentiation-inducing agent, on human breast carci- 
noma MCF-7 cells and xenografts. Breast Cancer Res 2005, 7:1097-1II0.

30. Buck E, Eyzaguirre A, Brown E, Petti F, McCormack S, Haley JD, Iwata KK, Gibson NW, Griffin G: Rapamycin synergizes with the epidermal growth factor receptor inhibitor erlotinib in nonsmall-cell lung, pancreatic, colon, and breast tumors. Mol Cancer Ther 2006, 5:2676-2684.

31. Mosley JD, Poirier JT, Seachrist DD, Landis MD, Keri RA: Rapamycin inhibits multiple stages of c-Neu/ErbB2 induced tumor progression in a transgenic mouse model of HER2-positive breast cancer. Mol Cancer Ther 2007, 6:2188-2197.

32. Mabuchi S, Altomare DA, Cheung M, Zhang L, Poulikakos PI, Hensley $\mathrm{HH}$, Schilder RJ, Ozols RF, Testa JR: RAD00I inhibits human ovarian cancer cell proliferation, enhances cisplatin-induced apoptosis, and prolongs survival in an ovarian cancer model. Clin Cancer Res 2007, 13:426I-4270.

33. Dowling RJ, Zakikhani M, Fantus IG, Pollak M, Sonenberg N: Metformin inhibits mammalian target of rapamycin-dependent translation initiation in breast cancer cells. Cancer Res 2007, 67:10804-10812.

34. Okada T, Sawada T, Kubota K: Rapamycin enhances the antitumor effect of gemcitabine in pancreatic cancer cells. Hepatogastroenterology 2007, 54:2I29-2I33.

Publish with Biomed Central and every scientist can read your work free of charge

"BioMed Central will be the most significant development for disseminating the results of biomedical research in our lifetime. "

Sir Paul Nurse, Cancer Research UK

Your research papers will be:

- available free of charge to the entire biomedical community

- peer reviewed and published immediately upon acceptance

- cited in PubMed and archived on PubMed Central

- yours - you keep the copyright 